\title{
Membiasakan Pola Hidup Sehat dan Bersih pada Anak Usia Dini Selama Pandemi Covid-19
}

\author{
Hana Ika Safitri ${ }^{1 凶}$, Harun $^{2}$ \\ Pendidikan Anak Usia Dini, Universitas Negeri Yogyakarta \\ DOI: $10.31004 /$ obsesi.v5i1.542
}

\begin{abstract}
Abstrak
Tujuan penelitian ini untuk mendeskripsikan cara membiasakan pola hidup sehat dan bersih pada anak usia dini selama pandemi covid-19. Penelitian ini dianalisis dengan metode kualitiatif deskriptif. Subjek dipilih menggunakan teknik sampel nonprobability sampling yaitu purposive sample (pemilihan sampel dengan pertimbangan tertentu). Penelitian menggunakan 12 subjek yang terdiri dari 4 orang guru dan 4 orang wali murid beserta anaknya. Penelitian ini menggunakan wawancara untuk mengumpukan data dengan proses analisis melalui tiga tahapan yaitu reduksi data, display data, dan kesimpulkan serta verifikasi data. Berdasarkan hasil wawancara dengan subjek penelitian disimpulkan bahwa membiasakan pola hidup sehat dan bersih pada anak pada masa pandemi covid-19 dapat dilakukan dengan cara mengingatkan anak untuk memakan-makanan yang bergizi seperti sayur dan buah, berolahraga teratur dan istirahat yang cukup serta melakukan berjemur setiap pagi sekitar 10-15 menit, mencuci tangan dengan sabun, dan menjaga kebersihan diri sendiri.
\end{abstract}

Kata kunci : pola hidup sehat dan bersih; covid-19; anak usia dini

\begin{abstract}
The purpose of this study was to describe how to get used to a healthy and clean lifestyle in childhood during the covid-19 pandemic. This study was analyzed with a descriptive qualitative method designed to describe. The subject was selected using a nonprobability sampling technique. Nonprobability sampling is a purposive sample (sample selection with specific considerations). This study not only used 12 subjects consisting of 4 teachers and 4 parents and child, but also used interviews to collect data with three stages of the analysis process, namely data reduction, data display, the conclusion and data verification. Based on the results of the interviews with research subject, it was concluded that accustoming a healthy and clean lifestyle for children during the pandemic Covid-19 can be done by reminding to eat nutritious vegetables and fruits, keep doing excercise, getting rest sufficiently, and drying off every morning for about 10-15 minutes, washing their hands with soap frequently and keep hygiene for themselves.
\end{abstract}

Keyword: healthy and clean lifestyle; covid-19; early childhood

Copyright (c) 2020 Hana Ika Safitri, Harun

$\square$ Corresponding author :

Email Address : hanaikasafitri@gmail.com ( Yogyakarta, Indonesia )

Received 19 Mei 2020, Accepted 20 June 2020, Published 27 June 2020 


\section{PENDAHULUAN}

Anak usia dini merupakan individu yang unik. Keunikan tersebut yang membedakan antara satu anak dengan anak yang lain. Pendidikan anak usia dini adalah suatu upaya pembinaan yang ditujukan kepada anak sejak lahir sampai dengan usia enam tahun yang dilakukan melalui pemberian rangsangan pendidikan untuk membantu pertumbuhan dan perkembangan jasmani dan rohani agar anak memiliki kesiapan dalam memasuki pendidikan lebih lanjut (UU Nomor 20 Tahun 2003 Tentang Sistem Pendidikan Nasional). Kurun usia tersebut anak sedang berada pada tahap perkembangan yang pesat sehingga sangat tepat untuk mengajarkan anak berbagai hal seperti membiasakan pola hidup sehat dan bersih.

Membiasakan pola hidup sehat dan bersih tidak hanya tanggung jawab guru namun juga tanggung jawab orangtua. Pembiasaaan pola hidup sehat dan bersih sangat cocok diterapkan sejak dini terlebih pada masa pandemi covid seperti saat ini. Pandemi covid-19 atau virus corona terjadi pada akhir Desember 2019, wabah pneumonia misterius yang ditandai dengan demam, batuk kering, flu dan kelelahan terjadi pertama kali di Wuhan China yang kemudian menyebar ke negara-negara lain termasuk Indonesia (Wu et al., 2020). Pemerintah Indonesia melalui Gugus Tugas Percepatan Penanganan COVID-19 (Gugus Tugas Nasional) mencatat pada tanggal 17 Juni 2020 total kasus positif covid-19 menjadi 41.431 orang (covid19.co.id, 2020). Data tersebut dari hari ke hari semakin meningkat sehingga menjadikan kewaspadaan semua pihak oleh sebab itu memprioritaskan kesehatan saat ini sangatlah penting.

Masa pandemi covid-19 menjadikan kesehatan prioritas utama sehingga pemerintah pusat dan daerah memberikan kebijakan untuk seluruh lembaga pendidikan dari jenjang pendidikan anak usia dini (PAUD) hingga perguruan tinggi melakukan study for home atau belajar dari rumah. Kebijakan tersebut diterapkan sebagai upaya pencegahan meluasnya virus covid-19 (Arifudin, 2020). Menteri pendidikan dan Kebudayaan turut memberikan pesan agar orang tua, siswa, dan guru menjaga kesehatan masing-masing sesuai protap dari Kemenkes terkait Covid-19, dan untuk mengikuti imbauan Presiden Jokowi agar belajar di rumah, bekerja di rumah, dan beribadah di rumah (Fajriah, 2020)

Kebijakan yang dikeluarkan pemerintah terkait dengan belajar dari rumah menuntut guru dan orangtua untuk membiasakan pola hidup sehat dan bersih dengan strategi yang menarik sesuai perkembangan anak agar anak tidak cepat bosan. Membiasakan pola hidup sehat dan bersih artinya memberikan kegiatan pada anak tentang hidup sehat dan bersih secara berulang-ulang sehingga menjadi kebiasaan (Wiranata, 2020). Membiasakan pola hidup sehat dan bersih pada anak sangat dipengaruhi oleh partisipasi orang tua. Orang tua menentukan pilihan layanan kesehatan yang berkualitas bagi anak termasuk makanan yang dimakan, aktivitas fisik yang dilakukan, dukungan emosional, dan kualitas lingkungan (Inderan \& Wayan Weta, 2018). Pengalaman yang diberikan kepada anak untuk mendukung kesadaran anak tentang kebersihan membantu anak menjadi pribadi yang mandiri. Oleh karena itu membiasakan hidup sehat dan bersih kepada anak dapat dilakukan melalui metode bermain peran di mana anak dapat langsung mempraktikkan kegiatan yang dicontohkan oleh guru atau orangtua sehingga akan jauh lebih mengesankan bagi anak daripada anak diberi tahu tanpa anak melakukan sendiri (Yufiarti et al., 2019).

Anak-anak yang telah dibiasakan dengan pola hidup sehat dan bersih sejak dini akan tumbuh dan berkembang dengan baik, menyenangkan dan dapat menyesuaikan diri dengan lingkungan (Wijayanti, 2017). Selain itu membiasakan hidup sehat dan bersih dapat mencegah berbagai penyakit serta diharapkan mampu memutus rantai penyebaran penyakit (Suyatmin \& Sukardi, 2018). Membiasakan pola hidup bersih dan sehat yang paling mudah diterapkan untuk anak usia dini yaitu mencuci tangan. Mencuci tangan dengan sabun merupakan salah satu kegiatan yang dapat mencegah penyakit menular pada tubuh (Arifiyanti \& Prasetyo, 2018). 
DOI: 10.31004/obsesi.v5i1.542

Membiasakan pola hidup sehat dan bersih merupakan perwujudan proses pembelajaran yang diberikan oleh guru dan orangtua yang dapat digunakan oleh anak untuk menolong diri sendiri (Vionalita \& Kusumaningtiar, 2017). Membiasakan pola hidup sehat dan bersih mampu meminimalkan masalah-masalah kesehatan. Manfaat membiasakan pola hidup sehat sejak dini yaitu meningkatnya kesehatan keluarga sehingga anak tidak mudah sakit, anak tumbuh menjadi pribadi yang cerdas, dan anak jauh lebih aktif dan semangat untuk menjalani hari-hari (Wiranata, 2020). Membiasaan hidup sehat dan bersih pada anak dapat dibantu dengan alat bantu visual seperti gambar dan infrastruktur (Yufiarti et al., 2019).

Cara membiasakan pola hidup sehat pada masa pandemi covid-19 seperti saat ini dapat dilakukan dengan melakukan aktivitas fisik,konsumsi makanan bergizi, sayuran,dan buah-buahan (Suyatmin \& Sukardi, 2018). Kebiasaan hidup bersih dapat diawali dengan kegiatan sederhana seperti mencuci tangan sebelum makan, menyikat gigi, membersihkan setelah buang air kecil, mandi, membuang sampah di tempatnya,membatasi penggunaan plastik, menggunakan air bersih, dan sebagainya(Yufiarti et al., 2019). Membiasakan pola hidup sehat dan bersih ketika pandemi covid 19 seperti saat ini memang sangat penting.

Namun pada masa pandemi covid-19 seperti saat ini masih banyak orang yang menyepelekan tentang kesehatannya terutama pada anak yang usianya muda yang merasa daya tahan tubuhnya kuat dan tidak bisa sakit (Natasya, 2020). Padahal virus covid-19 ini dapat menyerang siapa saja, baik itu orang muda, orang tua bahkan yang masih anak-anak. Seseorang yang membawa virus covid-19 bisa saja tidak menunjukkan gejala yang signifikan dikarenakan daya tahan tubuhnya yang kuat namun orang tersebut dapat menularkan virus covid kepada orang lain, dan dapat berakibat fatal kepada orang lain karena daya tahan tubuhnya yang tidak sekuat orang yang membawa virus tersebut. Oleh karena itu membiasakan pola hidup sehat dan bersih sangat penting diterapkan pada masa pandemi covid-19 ini paling tidak untuk menjaga diri sendiri dan keluarga yang disayangi. Menjaga kesehatan pada anak usia sekolah juga dapat mempengaruhi hasil belajar serta mempengaruhi kegiatan sosial anak (Fatimawati, 2017).

Cara sederhana membiasakan pola hidup sehat dan bersih pada masa pandemi ini yaitu menerapkan cuci tangan menggunakan sabun. Namun jika dilihat per provinsi di Indonesia, masih banyak yang belum menerapkan mencuci tangan dengan sabun dan air (Rosalina, 2020). Kebiasaan masyarakat untuk menjaga lingkungan rumah tetap bersih juga mulai terlihat namun keluarga memprioritaskan membersihkan bagian rumah yang terlihat saja seperti ruang tamu sedangkan dapur dan kamar mandi tidak menjadi prioritas untuk dibersihkan.

Masa pandemi covid-19 ini masyarakat dihimbau untuk mengkonsumsi makanan yang sehat seperti buah dan sayur. Riset Kesehatan Dasar Kementerian Kesehatan 2018 mencatat, konsumsi sayur dan buah masyarakat Indonesia dikategorikan kurang. Mayoritas (66,5 persen) tercatat mengonsumsi makanan serat tersebut 1-2 porsi per hari dalam seminggu. Padahal menurut WHO, penduduk dikategorikan 'cukup' konsumsi sayur/buah jika mengonsumsinya minimal 5 porsi per hari dalam seminggu (Rosalina, 2020). Sayur dan buah juga lebih banyak dikonsumsi oleh orang yang berusia 30 tahun ke atas ketimbang usia anak dan remaja padahal usia anak dan remaja juga membutuhkan asupan vitamin dan mineral yang cukup untuk pertumbuhan dan menjaga daya tahan tubuh. Makanan yang sehat harus diimbangi dengan olahraga rutin. Orang yang gemar berolahraga akan memiliki daya tahan tubuh yang lebih baik, sehingga jarang terkena serangan penyakit. Namun, belum semua masyarakat punya kebiasaan berolahraga terlebih pada masa pandemi covid 19 seperti saat ini menyebabkan anak-anak malas berolahraga karena bukan guru yang mengajari anak melainkan orangtua (Rosalina, 2020).

Berdasarkan pemaparan di atas membiasakan pola hidup sehat dan bersih sangat penting untuk perkembangan anak terutama anak usia dini terlebih pada masa pandemi covid-19 seperti saat ini membiasakan pola hidup sehat dan bersih dapat meminimalkan 
penyebaran virus terhadap keluarga dan orang-orang yang tersayang. Oleh karena itu, penelitian ini bertujuan mengetahui pembiasaan pola hidup sehat dan bersih kepada anak usia dini pada masa panedemi covid-19 untuk diberikan solusi permasalahan yang timbul pada pembiasaan tersebut.

\section{METODOLOGI}

Penelitian ini dianalisis dengan metode kualitiatif deskriptif yang dirancang untuk mendeskripsikan membiasakan hidup sehat dan bersih pada anak usia dini pada masa pandemi covid-19. Subjek dipilih menggunakan teknik sampel nonprobability sampling yaitu purposive sample (pemilihan sampel dengan pertimbangan tertentu). Kriteria pemilihan sampel yaitu: 1) Orangtua yang memiliki anak usia 2-6 Tahun 2) Orangtua atau guru tinggal di daerah kabupaten Bantul 3) guru yang mengajar di lembaga PAUD daerah Kabupaten Bantul. Penelitian menggunakan 12 subjek yang terdiri dari 4 orang guru dan 4 orang wali murid beserta anaknya. Peneliti melakukan wawancara terhadap beberapa orang guru dan orangtua wali murid. Berdasarkan hasil wawancara peneliti ditentukan 12 subjek yang memenuhi kriteria pemilihan sampel.

Penelitian ini menggunakan wawancara untuk mengumpukan data dengan proses analisis melalui tiga tahapan yaitu reduksi data, display data, dan kesimpulkan serta verifikasi data. Reduksi data berarti merangkum, memilih data yang penting, memberikan kode dan membuang data yang tidak penting (Sugiyono, 2011). Display data atau penyajian data adalah memaparkan data yang sudah melalui tahapan reduksi sehingga memungkinkan adanya penarikan kesimpulan dan pengambilan tindakan (Sugiyono, 2011). Kesimpulan dan verifikasi data, penarikan kesimpulan merupakan hasil penelitian yang menjawab fokus penelitian berdasarkan hasil analisis data (Sugiyono, 2011).

Data wawancara diperoleh dengan wawancara mendalam dengan orangtua dan guru lembaga PAUD dengan menanyakan pembiasaan pola hidup sehat dan bersih selama di rumah dan peran guru dalam membantu orangtua untuk membiasakan pola hidup sehat dan bersih di rumah selama pandemi covid-19. Wawancara mendalam dengan orangtua dan guru dilengkapi dengan hasil wawancara dengan anak. Data yang tidak sesuai dengan fokus penelitian dihilangkan atau dibuang dan data yang sesuai dianalisis dan dijabarkan menggunakan pendekatan deskriptif. Penelitian dilakukan pada bulan April 2020.

Penelitian ini dilakukan terhadap guru dan orangtua wali murid beserta anaknya kabupaten Bantul, Yogyakarta. Guru PAUD tersebut terdiri dari 3 orang perempuan berisial $\mathrm{DL}, \mathrm{AK}$, dan FN, sedangkan satu orang guru berjenis kelamin laki-laki dengan inisial AD. Subjek Orangtua murid terdiri dari 4 orang perempuan dengan inisial DT, TY, IY dan FT beserta anaknya yang berinisial $A Z, R D, A B$, dan $H N$. Berikut bagan penelitian yang akan dilakukan oleh peneliti.

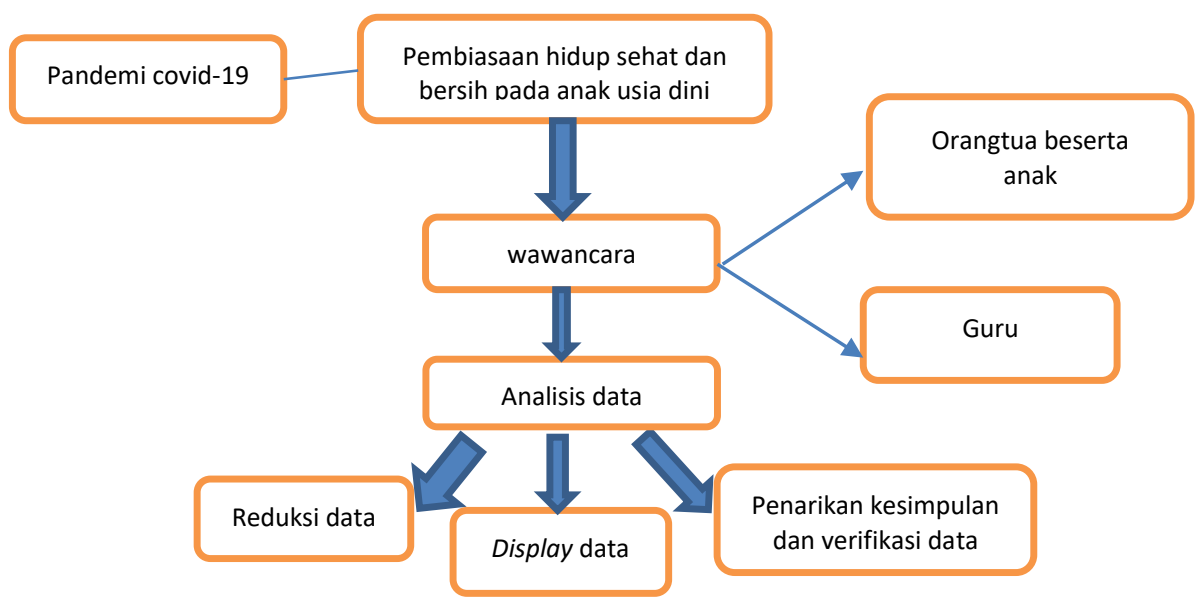

Gambar 1. Bagan metode penelitian 


\section{HASIL DAN PEMBAHASAN}

Perilaku hidup sehat dan bersih anak dapat terlihat di rumah selama masa pandemi covid-19 seperti saat ini. Pembiasaan pola hidup sehat dan bersih yang diterapkan pada anak di rumah berbeda-beda, cara guru membiasakan pola hidup sehat dan bersih kepada anak pun berbeda pula. Pengetahuan tentang pola hidup sehat dan bersih pada anak perlu diberikan sejak dini. Pengetahuan yang diberikan pada anak sejak dini diharapkan mampu membentuk kesadaran diri pada anak terkait pentingnya membiasakan pola hidup sehat dan bersih. Pola hidup sehat dan bersih merupakan latihan yang dipraktekkan secara sadar sebagai hasil belajar untuk menolong diri sendiri dan keluarga dalam bidang kesehatan(Wiranata, 2020). Membiasakan pola hidup sehat dan bersih pada anak usia dini mampu menciptakan individu yang mandiri dalam mencapai kesehatan(Yufiarti et al., 2019). Pembiasaan perilaku hidup sehat dan bersih mewujudkan keluarga yang sehat sehingga meningkatkan kesehatan fisik, mental, spiritual dan sosial yang baik (Arifin et al., 2015). Membiasakan pola hidup sehat dan bersih ini digunakan untuk menjaga, meningkatkan kesehatan, menghindari atau mencegah penyakit, melindungi diri dari berbagai penyakit, dan berpartisipasi dalam meningkatkan kualitas kesehatan (Suyatmin \& Sukardi, 2018). Tubuh yang sehat diperoleh dari aktivitas fisik,konsumsi makanan pokok, sayuran, dan buah-buahan, serta menjaga kebersihan (Suyatmin \& Sukardi, 2018). Pembiasaan pola hidup sehat sangat tepat dibiasakan sejak dini dikarenakan pada usia kurang dari 5 tahun rentan terhadap virus dan penyakit (Clark et al., 2016).

Semakin menyebarnya virus covid-19 saat ini merupakan saat yang tepat untuk melindungi dan meningkatkan kesehatan. Makan sehat sangat penting untuk menjaga sistem kekebalan tubuh dalam kondisi prima. Pembiasaan pola hidup sehat dan bersih yang diterapkan pada anak usia dini melalui berbagai cara yang sederhana dan mudah dipahami oleh anak. Pembiasaan pola hidup sehat dan bersih dapat dilihat dengan membiasakan olahraga teratur, berisitirahat yang cukup dan memakan-makanan yang bergizi. Hasil wawancara dengan empat orang guru dapat disimpulkan bahwa guru selalu mengingatkan anak untuk melakukan pola hidup sehat dan bersih dengan cara memberikan kegiatan kepada anak melalui orangtua anak. Guru mengirimkan video kegiatan kepada anak kemudian anak menirukan kegiatan guru, sebagai bukti orangtua merekam kegiatan anak dan mengirimkan kembali kepada guru. Pembiasaan pola hidup sehat dan bersih pada anak dapat diterapkan dengan metode pemodelan yaitu teknik yang dilakukan dengan memberikan contoh kepada anak kemudian anak secara langsung mempraktekkan apa yang telah dicontohkan oleh guru atau orangtua (Arifiyanti \& Prasetyo, 2018). Sebagai contoh seperti guru mengirimkan video tata cara mencuci tangan dengan baik dan benar kemudian anak mengikuti instruksi dari guru, orangtua merekam kegiatan anak kemudian di kirimkan kembali kepada guru.

"Kami selaku guru selalu memberikan kegiatan untuk menerapkan pola hidup sehat dan bersih di rumah apalagi saat pandemi covid-19 seperti saat ini". Kegiatan yang diberikan seperti melakukan olahraga kecil dengan berlari-lari, berjalan jinjit, ingkling sambil membilang, kami juga selalu mengingatkan untuk memakan-makanan yang bergizi berupa sayur dan buah, dan istirahat yang cukup. Kami selaku guru memberikan kegiatan yang sederhana dan dapat dilakukan bersamasama dengan orangtua anak, kami meminta orangtua selalu merekam kegiatan anak dan melaporkannya kepada kami". Kegiatan tersebut dilakukan terus-menurus sehingga menjadi kebiasaan bagi anak. "Kami biasanya memberikan perintah berupa video atau rekaman suara dikarenakan anak biasanya tidak mau mengerjakan kegiatan apabila yang memerintahkan orangtua". Perintah yang diberikan oleh guru di buat rekaman suara agar anak langsung bisa mendengarkannya.

Awalnya orangtua merasa kesulitan untuk menerapkan pola hidup sehat dan bersih kepada anak namun lama-kelamaan anak sudah mulai memahami dan mengerti pentingnya membiasakan pola hidup sehat dan bersih. "Awalnya kami sebagai orangtua kesulitan untuk membiasakan anak melakukan kegiatan yang berkaitan dengan pola hidup sehat dan bersih namun 
lama-kelamaan karena guru memberikan kegiatan dengan video atau rekaman suara akhirnya anak mau melakukan dan sekarang justru tidak perlu di ingatkan kembali". Anak bercerita awalnya tidak tahu kenapa harus selalu cuci tangan dengan sabun setelah melakukan aktifitas. Namun karena orangtua selalu mengingatkan, selalu bercerita ditambah dengan cerita dari guru menyebabkan anak-anak menjadi paham dan mengerti bahwa ada pandemi covid-19. "Aku sekarang rajin cuci tangan dan aku sekarang suka makan sayur dan buah, setiap pagi aku juga mengajak ayah dan bunda untuk berjemur sambil bermain".

Menanamkan perilaku hidup sehat dan bersih sedini mungkin lebih menjamin tercapainya masyarakat dengan perilaku hidup bersih dan sehat yang baik ketika mereka dewasa kelak. Pembiasaan pola hidup sehat dan bersih pada anak usia dini harus dilakukan dengan adanya kerjasama antara guru dan orangtua (Idhayani \& Fatmawati, 2018). Apabila guru dan orangtua tidak bekerja sama dengan baik maka akan mustahil untuk menghasilkan perubahan pada sikap anak. Temuan dilapangan terbukti adanya kerjasama yang baik antara keduanya. Orangtua sebagai lingkungan terdekat dengan anak mampu memberikan contoh kepada anak bagaimana menerapkan pola hidup sehat dan bersih (van de Kolk et al., 2018). Guru selalu mengingatkan anak-anak untuk mencuci tangan dengan benar menggunakan sabun dan orangtua memberikan fasilitas seperti sabun dan tempat cuci tangan yang mudah dijangkau oleh anak (Arifiyanti \& Prasetyo, 2018). Perilaku hidup bersih dan sehat adalah perwujudan dari proses belajar anak baik di rumah maupun di sekolah sehingga memunculkan kebiasaan dan kesadaran pada anak tentang pentingnya kesehatan (Vionalita \& Kusumaningtiar, 2017). Orang tua dan pendidik hendaknya terus memberikan contoh-contoh perilaku kebersihan lingkungan pada anak usia dini sehingga mudah ditiru dan diikuti oleh anak. Melakukan dengan cara-cara yang menarik dan menyenangkan, seperti bermain karena dunia anak adalah dunia bermain. Melalui permainan, anak akan merasa senang untuk meniru sehingga mau melakukan perilaku sehat tersebut (Astuti, 2016).

"Kami selaku guru memberikan kegiatan yang membiasakan pola hidup bersih secara sederhana seperti mencuci tangan dengan sabun". Anak-anak mengikuti arahan yang diberikan oleh guru dan orangtua membuat rekaman kegiatan yang dilakukan oleh anak setelah itu video dikirimkan kepada guru sebagai laporan kegiatan anak yang dilakukan pada satu hari tersebut. "Kami selaku orangtua memberikan fasilitas untuk anak seperti adanya tempat cuci tangan yang mudah dijangkau oleh anak dan tempat membuang sampah yang dapat dijangkau oleh anak, selain itu kami juga mengingatkan anak untuk selalu menjaga kebersihan diri dan lingkungan". Berdasarkan keterangan dari anak orangtua selalu menemani kegiatan anak sehari-hari. "Bunda selalu menemani kegiatan aku ketika dirumah, bunda juga suka merekam apa yang aku lakukan, katanya buat laporan kepada bu guru".

Pembiasaan pola hidup sehat pada masa pandemi yang diterapkan pada anak usia dini seperti makan-makanan yang bergizi. Makanan yang bernutrisi seperti biji-bijian, sayuran, dan buah-buahan merupakan makanan yang baik untuk menjaga stamina tubuh (Byrd-Bredbenner et al., 2020). Berdasarkan hasil wawancara dengan guru dan orangtua sepakat bahwa anak harus dibiasakan untuk memakan-makanan yang bergizi seperti buah, dan sayur. Orangtua juga memberikan susu kepada anak untuk menambah stamina anak. Anak juga harus dibiasakan untuk melakukan aktifitas fisik seperti senam, bersepeda atau kejar-kejaran di rumah. Aktivitas fisik luar ruang dapat membantu anak-anak memproses iklim sosial yang tidak biasa, membantu anak-anak tidur lebih baik, karena dosis energi yang sehat dilepaskan sepanjang hari (Joel, 2020). Aktifitas fisik yang dilakukan oleh anak dapat mengurangi risiko infeksi pernapasan, dan membangun ketahanan fisik anak (Conti, 2020). Berdasarkan wawancara dengan orangtua dapat disimpulkan bahwa sebagian kebanyakan orangtua telah membiasakan anak untuk beraktifitas fisik seperti bersepeda bersama, bermain bersama bahkan melakukan senam bersama. 
DOI: 10.31004/obsesi.v5i1.542

"Sebagai orang tua saya juga membiasakan anak untuk melakukan kegiatan yang berhubungan dengan pola hidup sehat dan bersih selain melaksanakan kegiatan yang diberikan oleh guru seperti mengajak untuk berjemur selama 10-15 menit, mmeberikan susu untuk menambah stamina anak. Saya juga menemari anak untuk bermain serta selalu mengajak anak untuk membersihkan rumah. Saya juga selalu menceritakan kepada anak pentingnya membiasakan pola hidup sehat dan bersih.

Pembiasaan pola hidup sehat dengan makan-makanan yang bergizi. Makanmakanan yang bergizi seperti buah dan sayur untuk memenuhi asupan nutrisi pada tubuh (Julianti, 2018). Buah dan sayuran segar menyediakan banyak vitamin dan mineral serta serat yang dibutuhkan untuk menjadi sehat. Selain makan-makanan yang bergizi harus tetap memperhatikan asupan air putih untuk minum agar tidak terjadi dehidrasi (FAO, 2020). Makan-makanan yang bergizi harus diimbangi dengan aktivitas tidur yang cukup pada anak. Tidur yang cukup dapat mempengaruhi aktivitas anak, semakin anak tidur dengan cukup maka anak tidak akan terlihat lelah, anak akan kelihatan aktif di pagi harinya (Kuzik et al., 2017). Tidur yang cukup menyebabkan aktivitas fisik menjadi aktif, anak tidak merasa lelah dan tidak merasa kantuk, serta membuat sistem metabolisme dalam tubuh menjadi lancar (Saunders et al., 2016). Makanan sehat mengandung gizi dan baik dikonsumsi oleh tubuh. Makanan sehat merupakan makanan yang bergizi, higienis, tidak mengandung kuman penyakit yang membahayakan kesehatan (Rahmawati \& Dewi, 2019).

"Sebagai orang tua saya juga membiasakan anak untuk melakukan kegiatan yang berhubungan dengan pola hidup sehat dan bersih selain melaksanakan kegiatan yang diberikan oleh guru seperti mengajak anak memasak sambil mengenalkan nama-nama sayur, mengajak anak untuk memasak bersama makanan yang akan dimakan anak". Kegiatan tersebut untuk membiasakan anak memakan-makanan yang bergizi.

Hasil wawancara dengan anak dapat disimpulkan bahwa anak telah melaksanakan pembiasaan pola hidup sehat dan bersih secara sederhana seperti mencuci tangan dengan sabun. Anak juga dibiasakan untuk menggosok gigi, memotong kuku dan membuang sampah pada tempatnya. Temuan di lapangan pada awalnya anak susah untuk dibiasakan untuk menerapkan pola hidup sehat dan bersih namun lama-kelamaan anak semakin paham dan mengerti bahwa menerapkan pola hidup sehat dan bersih dapat meningkatkan kesehatan. Orangtua dan guru tidak henti-hentinya selalu mengingatkan dan mengajarkan anak untuk selalu menerapkan pola hidup sehat dan bersih kepada anak. Oleh karena itu sangat penting adanya kerjasama antara guru dan orangtua (Yana \& Husin, 2019).

"Kami selaku guru memberikan kegiatan yang membiasakan pola hidup bersih secara sederhana seperti mencuci tangan dengan sabun". Pernyataan guru diperkuat dengan wawancara kepada anak. "Setelah melakukan kegiatan aku selalu mencuci tangan, lalu ketika pergi dari rumah aku selalu menggunakan masker". Awalnya anak mengaku tidak tahu apa yang sedang terjadi namun lama kelamaan anak menjadi paham dikarenakan guru dan orangtua selalu memberikan pengertian kepada anak tentang adanya pandemi covid-19. "Kata ibu guru dan bunda saat ini sedang ada pandemi covid-19 jadi aku harus jaga kebersihan dengan rajin cuci tangan pakai sabun".

Pembiasaan pola hidup bersih yang dapat dilakukan oleh anak usia dini seperti mencuci tangan dengan sabun, memotong kuku dan membuang sampah pada tempatnya. Mencuci tangan dengan sabun merupakan salah satu kegiatan yang dapat mencegah penyakit menular pada tubuh (Clark et al., 2016). Mencuci tangan menggunakan sabun dapat mengatasi penyebaran virus, dan berbagai penyakit (Azor-Martinez et al., 2018). Pembiasaan pola hidup sehat dan bersih dilakukan terus menerus agar menjadi kebiasaan baik bagi anak. Kebiasaan hidup bersih pada anak-anak, terutama pada anak usia dini dapat dibantu dengan alat bantu visual seperti gambar dan infrastruktur. Alat peraga berupa gambar-gambar seperti menempel gambar cara mencuci tangan dengan benar menyediakan tempat mencuci tangan yang mudah dijangkau oleh anak (Yufiarti et al., 2019). 
Pembiasaan pola hidup sehat dan bersih pada anak usia dini bertujuan untuk meningkatkan kesehatan anak. Kesehatan merupakan modal dasar untuk melakukan semua kegiatan. Kesehatan yang buruk mengakibatkan banyak ancaman dan bahaya terutama bagi anak usia dini. Ancaman tersebut seperti penyakit yang disebabkan virus ataupun bakteri maupun jamur (Suyatmin \& Sukardi, 2018). Pembiasaan pola hidup sehat dan bersih pada anak diharapkan dapat memutus rantai penyebaran penyakit. Anak-anak yang sehat akan berkembang sesuai usia, bersih, menyenangkan, dan dapat menyesuaikan diri dengan lingkungan (Wijayanti, 2017).

\section{SIMPULAN}

Berdasarkan hasil wawancara dengan guru lembaga PAUD dan orangtua siswa dapat disimpulkan bahwa membiasakan pola hidup sehat pada anak pada masa pandemi covid-19 dapat dilakukan dengan cara mengingatkan anak untuk memakan-makanan yang bergizi seperti sayur dan buah, berolahraga teratur dan istirahat yang cukup serta berjemur setiap pagi sekitar 10-15 menit. Selain mengingatkan guru juga memberikan kegiatan sederhana kepada anak yang disampaikan melalui rekaman video atau rekaman suara kepada anak. Sedangkan untuk menerapkan pola hidup bersih berdasarkan hasil wawancara dengan guru lembaga PAUD dan orangtua siswa dapat disimpulkan bahwa guru memberikan kegiatan untuk membiasakan pola hidup bersih kepada anak seperti membiasakan anak melakukan cuci tangan dengan sabun, dan menjaga kebersihan diri sendiri. Pembiasaan pola hidup sehat dan bersih dapat terwujud apabila ada kerjasama antara guru dan orangtua. Penelitian ini dapat membantu guru mengetahui bagaimana cara membiasakan pola hidup sehat dan bersih pada anak usia dini selama pandemi covid-19.

\section{UCAPAN TERIMAKASIH}

Peneliti mengucapkan terima kasih sedalam-dalamnya kepada Allah SWT atas limpahan dan karunianya sehingga peneliti dapat melaksanakan penelitian dan menyelesaikan artikel ilmiah ini. Dosen pembimbing yang telah memberikan arahan serta masukan selama menyusun karya ilmiah ini, orangtua yang telah memberikan doa dan dukungan kepada saya, Subjek penelitian atas kerjasamanya serta informasi yang diberikan sehingga penulis dapat menyelesaikan karya ilmiah ini serta semua pihak yang telah membantu penulis.

\section{DAFTAR PUSTAKA}

Arifin, S., Heriyani, F., Rahman, F., \& Anhar, V. Y. (2015). Cultural Study on the Behavior of Clean and Healthy in Order of Household in Order to Increase Health Status in South Kalimantan. Asian Journal of Applied Sciences, 03(03), 10.

Arifiyanti, N., \& Prasetyo, I. (2018). Personal Hygiene Learning in Preschool Classroom. 7(2), 8. https:/ / doi.org/DOI 10.15294/IJECES.V7I2.23170

Arifudin, O. (n.d.). Pandemi Corona dan Dampak Terhadap Dunia Pendidikan. https://www.pasundanekspres.co/opini/pandemi-corona-dan-dampak-terhadapdunia-pendidikan/

Arikunto, S. (2010). Prosedur penelitian: Suatu pendekatan praktik.

Astuti, A. K. (2016). Pelaksanaan perilaku sehat pada anak usia dini di paud purwomukti desa batur kecamatan getasan. Scholaria: Jurnal Pendidikan dan Kebudayaan, 6(3), 264. https:// doi.org/10.24246/j.scholaria.2016.v6.i3.p264-272

Azor-Martinez, E., Yui-Hifume, R., Muñoz-Vico, F. J., Jimenez-Noguera, E., Strizzi, J. M., Martinez-Martinez, I., Garcia-Fernandez, L., Seijas-Vazquez, M. L., Torres-Alegre, P., Fernández-Campos, M. A., \& Gimenez-Sanchez, F. (2018). Effectiveness of a Hand Hygiene Program at Child Care Centers: A Cluster Randomized Trial. Pediatrics, 142(5), e20181245. https:/ / doi.org/10.1542/ peds.2018-1245 
DOI: 10.31004/obsesi.v5i1.542

Byrd-Bredbenner, C., Eck, K., \& Abbot, J. M. (2020). Making Health and Nutrition a Priority During the Coronavirus (COVID-19) Pandemic. https://nutrition.org/making-healthand-nutrition-a-priority-during-the-coronavirus-covid-19-pandemic/

Clark, J., Henk, J. K., Crandall, P. G., Crandall, M. A., \& O'Bryan, C. A. (2016). An observational study of handwashing compliance in a child care facility. American Journal of Infection Control, 44(12), 1469-1474. https://doi.org/10.1016/j.ajic.2016.08.006

Conti, G. (n.d.). Supporting parents and children in the early years during (and after) the COVID19 crisis. https://voxeu.org/article/supporting-parents-and-children-early-yearsduring-and-after-covid-19-crisis

covid19.co.id. (2020). Kasus Positif COVID-19 Naik 1.031, Pasien Sembuh Meningkat Jadi 16.234. https:/ / covid19.go.id/p/berita/kasus-positif-covid-19-naik-1031-pasien-sembuhmeningkat-jadi-16234

Fajriah, W. (2020.). Tips dan Trik Belajar di Rumah saat Pandemi COVID-19. https://news.okezone.com/read/2020/04/09/65/2196931/tips-dan-trik-belajar-dirumah-saat-pandemi-covid-19

FAO. (2020). Maintaining a healthy diet during the COVID-19 pandemic. http://www.fao.org/documents/card/en/c/ca8380en/

Fatimawati, I. (2017). Study of Clean and Healthy Life Behavior of Elementary School Student at Schools Applying Adiwiyata Program at State Elementary School in Prigen Pasuruan. 7.

Idhayani, N., \& Fatmawati, D. (2018). Analisis pembiasaan perilaku hidup sehat pada anak kelompok $b$ tk harapan pertiwi desa anggalomoare kecamatan anggalomoare. Jurnal Smart Paud, 1(1), 16. https://doi.org/10.36709/jspaud.v1i1.3516

Inderan, S. R., \& Wayan Weta2. (2018). Correlation between clean and healthy lifestyle behavior of mother with the incident of diarrhea in toddlers at working area of Puskesmas I Negara, Jembrana-Bali. Volume 9(Number 3: 14-20). https://doi.org/doi: 10.15562/ism.v9i3.180

Joel. (2020). Guidance on Healthy Movement Behaviours for Kids During the COVID-19 Pandemic. https:/ / www.activehealthykids.org/2020/04/06/guidance-on-healthy-movementbehaviours-for-kids-during-the-covid-19-pandemic/

Julianti, R. (2018). Pelaksanaan perilaku hidup bersih dan sehat (phbs) di lingkungan sekolah. 3, 7. https://doi.org/10.33221/jikm.v7i01.46.

Kuzik, N., Poitras, V. J., Tremblay, M. S., Lee, E.-Y., Hunter, S., \& Carson, V. (2017). Systematic review of the relationships between combinations of movement behaviours and health indicators in the early years (0-4 years). BMC Public Health, 17(S5), 849. https:// doi.org/10.1186/s12889-017-4851-1

Natasya, K. (2020). Pola Hidup Sehat Selama Pandemi Covid-19. https://www.goriau.com/berita/baca/pola-hidup-sehat-selama-pandemicovid19.html

Rahmawati, M. C., \& Dewi, N. D. L. (2019). Instilling Clean and Healthy Life Behavior in Paud Atmabrata, Cilincing, Jakarta. MITRA: Jurnal Pemberdayaan Masyarakat, 3(1), 41-49. https://doi.org/10.25170/mitra.v3i1.499

Rosalina, M. P. (2020). Hidup Sehat Menangkal Corona. https:/ / kompas.id/baca/riset/2020/04/03/hidup-sehat-menangkal-korona/

Saunders, T. J., Gray, C. E., Poitras, V. J., Chaput, J.-P., Janssen, I., Katzmarzyk, P. T., Olds, T., Connor Gorber, S., Kho, M. E., Sampson, M., Tremblay, M. S., \& Carson, V. (2016). Combinations of physical activity, sedentary behaviour and sleep: Relationships with health indicators in school-aged children and youth. Applied Physiology, Nutrition, and Metabolism, 41(6 (Suppl. 3)), S283-S293. https:/ / doi.org/10.1139/apnm-2015-0626

Sugiyono. (2011). Metode penelitian kuantitatif dan kualitatif dan $r \mathcal{E} d$. Alfabeta. 
Suyatmin, S., \& Sukardi, S. (2018). Development of Hygiene and Healthy Living Habits Learning Module for Early Childhood Education Teachers. Unnes Journal of Public Health, 7(2), 89-97. https:/ / doi.org/10.15294/ ujph.v7i2.19470

UU Nomor 20 Tahun 2003 Tentang Sistem Pendidikan Nasional. (n.d.). http://hukum.unsrat.ac.id/uu/uu_20_03.htm

Van de Kolk, I., Goossens, A., Gerards, S., Kremers, S., Manders, R., \& Gubbels, J. (2018). Healthy Nutrition and Physical Activity in Childcare: Views from Childcare Managers, Childcare Workers and Parents on Influential Factors. International Journal of Environmental Research and Public Health, 15(12), 2909. https:// doi.org/10.3390/ijerph15122909

Vionalita, G., \& Kusumaningtiar, D. (2017). Knowledge of Clean and Healthy Behavior and Quality of Life among School-Children. Proceedings of the Health Science International Conference (HSIC 2017). Health Science International Conference (HSIC 2017), Malang, Indonesia. https:/ / doi.org/10.2991/hsic-17.2017.67

Wijayanti, N. A. (2017). Implementation of Role Playing Method in the Hygiene Hadith Learning Toward Early Children's Healthy Behavior of Group B in Dabin Aggrek Gunungpati Semarang. 5.

Wiranata, I. G. L. A. (2020). Penerapan Positive Parenting dalam Pembiasaan Pola Hidup Bersih dan Sehat kepada Anak Usia Dini. 7.

Wu, Y.-C., Chen, C.-S., \& Chan, Y.-J. (2020). The outbreak of COVID-19: An overview. Journal of the Chinese Medical Association, 83(3), 217-220. https:// doi.org/10.1097/JCMA.0000000000000270

Yana, L. F., \& Husin, A. (2019). Kebiasaan hidup bersih dan sehat pada anak usia dini di kampung 1 desa muara beliti baru kabupaten musi rawas. 12.

Yufiarti, Y., Edwita, \& Suharti. (2019). Health Promotion Program (JUMSIH); To Enhance Children's Clean and Healthy Living Knowledge. JPUD - Jurnal Pendidikan Usia Dini, 13(2), 341-355. https:// doi.org/10.21009/JPUD.132.10 